\title{
The limits of laws: Traffic law enforcement in South Africa
}

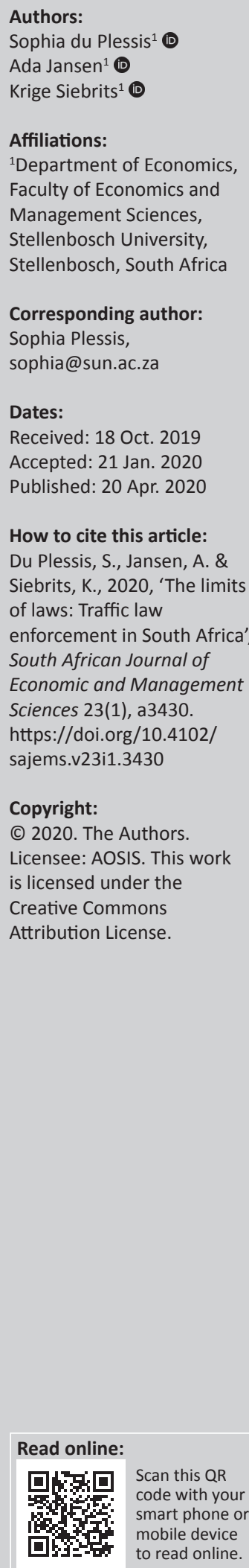

Background: The aim of many public policies is to change behaviour. Governments tend to rely on regulations, taxes and subsidies to effect such change. These measures, which affect agents' economic incentives, have a mixed record. A key insight of the New Institutional Economics is that the efficacy of such formal institutions depends on the strength of their enforcement and the extent to which they are compatible with prevailing informal institutions.

Aim: This article uses the road safety situation in South Africa as a case study to explore aspects of the relationships among formal institutions, law enforcement and informal institutions.

Setting: South Africa has a strong suite of road safety laws but poor road safety outcomes.

Methods: The article draws on ideas about the relationships between formal institutions, law enforcement and informal institutions to undertake a case study of the road safety situation in South Africa.

Results: The article argues that improved law enforcement cannot fully solve the problem; complementary changes to the informal institutions shaping the behaviour of road users are essential.

Conclusion: Institutional economists have to take a greater interest in the insights of research in behavioural economics, behavioural and cognitive science and other disciplines in order to provide useful advice in settings where such change is an important policy objective.

Keywords: traffic laws; formal institutions; law enforcement; informal institutions; South africa.

\section{Introduction}

The aim of many public policies is to change behaviour. To achieve this aim, governments mostly rely on regulations, taxes and subsidies. ${ }^{1}$ These measures affect the economic incentives of agents: taxes and subsidies change prices, while non-compliance with many regulations carries costly sanctions. Economic incentives have a mixed record as devices for changing behaviour. As Bowles and Polanía-Reyes (2012:369) put it: 'Incentives work, often affecting the targeted behaviour almost exactly as conventional economic theory predicts. ... But explicit economic incentives sometimes have surprisingly limited effects, and may even be counterproductive'.

Ideas from the New Institutional Economics are valuable for understanding the varied effects of economic incentives. ${ }^{2}$ Institutional economists distinguish between two types of constraints that influence human behaviour, namely formal institutions (e.g. policy rules, constitutions and other laws) and informal institutions (e.g. norms of behaviour, conventions and self-imposed codes of conduct) (North 1994:360). Regulations, taxes and subsidies are examples of formal institutions. One of the key insights of institutional economists is that the effectiveness of such institutions depends on the strength of their enforcement and the extent to which they are compatible with the prevailing informal institutions. North (2005) summarises this insight as follows:

The policies at our disposal are very blunt instruments. They consist of alterations in the formal rules only, when in fact ... performance ... is an admixture of the formal rules, the informal norms, and their enforcement characteristics. Changing only the formal rules will produce the desired results only when the informal norms that are complementary to that rule change and enforcement is either perfect or at least consistent with the expectations of those altering the rules. (pp. 27-28)

1.Nudging has recently emerged as an alternative or a complementary policy approach for effecting behavioural change (cf. Section 6). 2.North's (1994:359) well-known statement that 'institutions form the incentive structure of a society' underscores the salience of incentives in the New Institutional Economics. 
The New Institutional Economics is not the only field in economics that recognises the interconnectedness of formal institutions, enforcement and informal institutions. Many microeconomists and behavioural economists now acknowledge that informal institutions influence the efficacy of incentives (cf. Festré 2010; Gneezy, Meier \& Rey-Biel 2011), and law enforcement has long been a major theme in the Law and Economics literature (cf. Polinsky \& Shavell 2007). Yet much scope remains for studying the ways in which enforcement and informal institutions influence the incentive effects of policies to change behaviour. The present article uses the road safety situation in South Africa as a case study to explore this issue.

\section{Conceptual framework}

Figure 1 presents a framework for conceptualising the core issues explored in this article. This framework is an adaptation of one suggested by Groenewegen, Spithoven and Van den Berg (2010:26-27, 33). Figure 1 depicts the institutional environment as a hierarchy of behaviour-influencing formal and informal institutions. ${ }^{3}$ The first two levels of the hierarchy consist of informal institutions. Values are 'generally-held preferences about pursuable goals, and embody what most citizens in a certain society consider to be "good" (Groenewegen et al. 2010:26). Norms are 'generally-held opinions about how to achieve the values' (Groenewegen et al. 2010:26). The notion that people should drive safely, for example, is a norm that contributes to the value of security. Values and norms are the bases of legally enforceable public rules (formal institutions, such as traffic laws) and informal private rules of behaviour (road safety-related practices that are not encapsulated in law yet widely applied). As was pointed out earlier, public and private rules and their enforcement jointly shape the behaviour of individuals. ${ }^{4}$

The source of the problem discussed in this article is the coexistence in societies of different sets of values and norms (Groenewegen et al. 2010:26). Some persons hold the same values and norms that underpin the legally enforceable public rules and choose corresponding informal private rules. Hence, they exhibit the forms of behaviour desired by policymakers. Enforcement of the public rules would be unnecessary if all persons behave in this manner; in fact, such rules would be superfluous. In most real-world situations, however, some persons choose informal private rules based on values and norms that give rise to inappropriate behaviour. This reality explains why governments create and enforce laws and other formal institutions to change behaviour.

This article applies the framework in Figure 1 to the road safety situation in South Africa as follows. The section that follows, on the road safety situation in South Africa, shows

3.Voigt and Kiwit (1998:84-88) provide alternative definitions of the elements of institutional environments and a well-considered exposition of the relationships between them.

4.This relationship is also captured in the 'interaction thesis' formulated by Pejovich (1999:171).

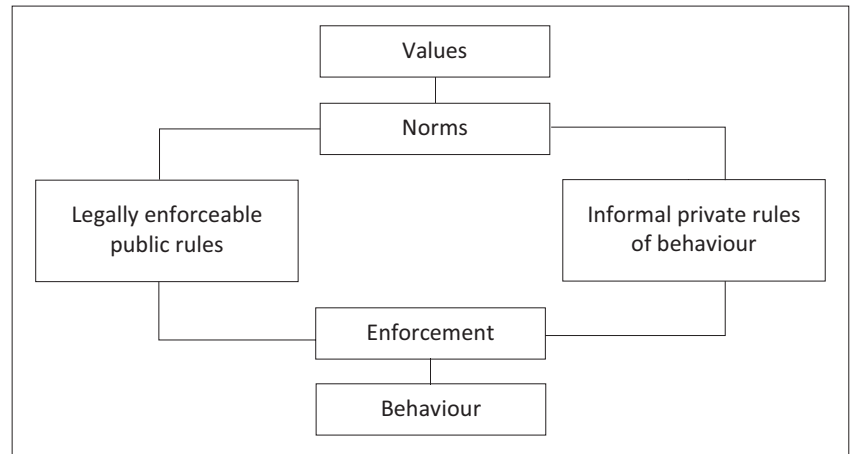

Source: Adapted from Groenewegen, J., Spithoven, A. \& Van den Berg, A., 2010, Institutional economics: An introduction, p. 33, Palgrave MacMillan, London.

FIGURE 1: Institutions, law enforcement and behaviour.

that the incidence of road accidents in South Africa is high and costly in spite of the country's relatively strong road safety laws. The limited efficacy of these laws confirms that the road safety situation in South Africa is a pertinent setting for studying the links among formal institutions, enforcement and informal institutions. The next two sections discuss the contributions to this state of affairs of informal institutions and law enforcement. The section on adherence to road safety laws in South Africa shows that road users in South Africa frequently violate road safety laws and argues that such behaviour partly reflects values and norms (i.e. informal institutions) that undermine obedience to such laws. The section on the enforcement of road safety laws in South Africa summarises the institutional framework governing the enforcement of road safety laws and presents evidence of the scope of law enforcement actions. It also uses information from an administrative data set of traffic law violations in the City of Cape Town from July 2014 to July 2016 to provide further insight into the enforcement of road safety laws. This information shows that it would be extremely difficult to eradicate leading causes of road accidents by means of law enforcement activities and that the structures for enforcing sanctions for law violations function extremely poorly. Against this backdrop, the article concludes that a combination of law enforcement reforms and changes to informal institutions is necessary to improve the road safety situation in South Africa. This section also points out that institutional economists' limited understanding of the roles and malleability of informal institutions constrains their ability to provide useful policy advice in this, as well as other contexts. Hence, it concludes that institutional economists should prioritise research into these issues and intensify their efforts to study relevant findings of psychologists and other social scientists.

\section{The road safety situation in South Africa}

The World Health Organisation (WHO) (2015:65) links road traffic deaths and injuries to seven major behavioural risk factors: speeding, driving under the influence, failure to use seatbelts, motorcycle helmets and child restraints, drunkdriving, and using mobile phones while driving. According 
TABLE 1: Road safety risk factors, legislative best practices and South African legislation.

\begin{tabular}{|c|c|c|}
\hline Risk factor & Laws and best practices & South Africa \\
\hline \multirow[t]{3}{*}{ Speeding } & National speed law in place & Yes \\
\hline & Speed limits on urban roads $\leq 50 \mathrm{~km} / \mathrm{h}$ & No \\
\hline & Local authorities may modify national speed limits & Yes \\
\hline \multirow{4}{*}{$\begin{array}{l}\text { Driving under } \\
\text { the influence }\end{array}$} & National driving under the influence law in place & Yes \\
\hline & Law enforcement based on BAC & Yes \\
\hline & BAC limit for general population $\leq 0.05 \mathrm{~g} / \mathrm{dl}$ & Yes \\
\hline & BAC limit for young or novice drivers $\leq 0.02 \mathrm{~g} / \mathrm{dl}$ & No \\
\hline \multirow{6}{*}{$\begin{array}{l}\text { Motorcycle } \\
\text { helmets }\end{array}$} & National motorcycle helmet law in place & Yes \\
\hline & $\begin{array}{l}\text { Applies to motorcycle drivers and adult } \\
\text { passengers }\end{array}$ & Yes \\
\hline & Applies to all road types & Yes \\
\hline & Applies to all engine types & Yes \\
\hline & Requires helmets to be properly fastened & Yes \\
\hline & $\begin{array}{l}\text { Requires helmets to meet a national or } \\
\text { international standard }\end{array}$ & No \\
\hline \multirow[t]{3}{*}{ Seat belts } & National seat belt law in place & Yes \\
\hline & Applies to drivers and front-seat passengers & Yes \\
\hline & Applies to rear-seat passengers & Yes \\
\hline \multirow{3}{*}{$\begin{array}{l}\text { Child } \\
\text { restraints }\end{array}$} & National child restraint law in place & Yes \\
\hline & Based on age-weight-height (or combination) & Yes \\
\hline & $\begin{array}{l}\text { Restricts children under a certain age from sitting } \\
\text { in the front seat }\end{array}$ & No \\
\hline Drug driving & National drug-driving law in place & Yes \\
\hline $\begin{array}{l}\text { Mobile } \\
\text { phones }\end{array}$ & $\begin{array}{l}\text { National law on mobile phone while driving } \\
\text { in place }\end{array}$ & Yes \\
\hline
\end{tabular}

Source: World Health Organisation, 2018, Global status report on road safety 2018, p. 235 World Health Organisation, Geneva.

$\mathrm{BAC}$, blood alcohol content.

to the $\mathrm{WHO}$, a strong legislative framework to reduce road traffic deaths and injuries should contain laws to regulate these risk factors. For the first five risk factors, the WHO recommends best practices that should be incorporated in such laws (evidence is still being gathered on legislative best practices with regard to drug driving and the use of mobile phones while driving). Table 1 lists these risk factors and the associated best practices recommended by the WHO. It also shows the extent to which South African road safety legislation conforms to international best practice.

Table 1 suggests that South Africa has a strong suite of road safety laws: the country has laws to deal with all seven risk factors. South Africa's seat belt laws are fully aligned with international best practice, while those on speeding, driving under the influence and motorcycle helmets each lacks only one element of such practices. Yet road safety outcomes are far from acceptable. According to the Road Traffic Management Corporation (RTMC) (2019:7), 12921 persons lost their lives on South Africa's roads in 2019; furthermore, $12.5 \%$ of non-natural deaths and $1.4 \%$ of all deaths in South Africa in 2016 were caused by transport accidents (Statistics South Africa 2017:45). An earlier report by the RTMC (2016b:32) shows that South Africa suffered 832431 road traffic crashes in 2015. Fully 11144 were fatal and a further 40117 major crashes. These crashes caused 13591 deaths, 62520 serious injuries and 202509 slight injuries. Modelling based on the latest techniques used in studies elsewhere revealed that the cost of road traffic crashes in 2015 amounted to 3.4\% of South Africa's gross domestic product (RTMC 2016b:36).

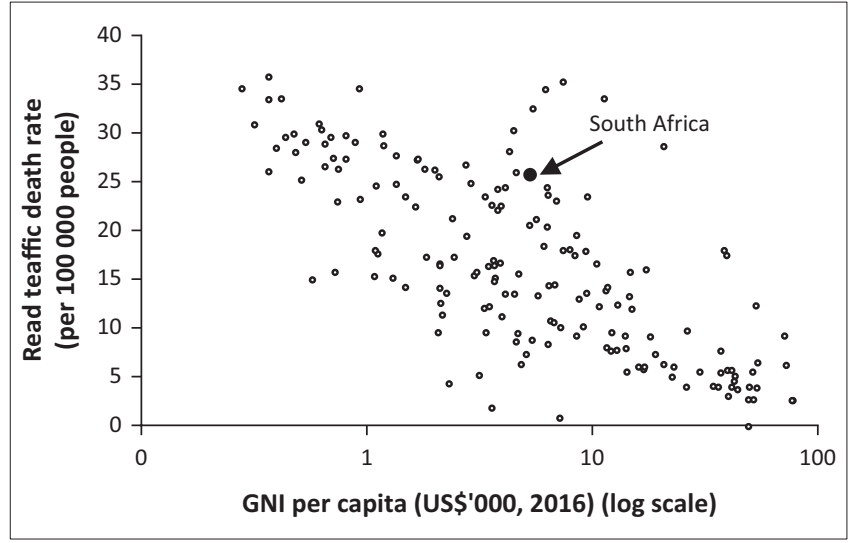

Source: World Health Organisation, 2018, Global status report on road safety 2018, pp. 302-313, World Health Organisation, Geneva.

GNI, Gross national income.

FIGURE 2: Road traffic deaths per 100000 of the population (2016).

International comparisons confirm the impression of unsatisfactory outcomes. Figure 2 shows that South Africa's road traffic death rate in 2016, namely 25.9 per 100000 of the population, was relatively high for an upper-middle-income country. In fact, the South African road traffic death rate exceeded the average rates for all middle-income countries (18.0) and high-income countries (7.7) and was only slightly lower than that for low-income countries (28.3) (these averages were calculated from the country rates in WHO 2018:302-313). Inconsistencies in the gathering and interpretation of data make international comparisons of estimates of the costs of road traffic crashes hazardous. It is notable, however, that the estimate for South Africa quoted above is higher than those for the majority of countries reported by Wijnen and Stipdonk (2016:105) (cf. Figure 3). The South African government is well aware of the scale of the problem. It endorsed the Decade of Action for Road Safety 2011-2020 proclaimed in March 2010 by the United Nations and included a major reduction in motor vehicle accidents among the goals of the National Development Plan 2030 (National Planning Commission 2015:298).

The New Institutional Economics suggests that the disjunction between South Africa's relatively strong road safety laws and the high and costly incidence of road accidents may well reflect inappropriate values and norms about prudent behaviour among road users, poor enforcement of road safety laws, or a combination of these two sets of factors. The following sections present evidence on this conjecture.

\section{Adherence to road safety laws in South Africa}

Survey data on the values and norms underpinning the behaviour of road users in South Africa do not exist. Hence, researchers interested in the nature and effects of such values and norms have to rely on proxies. The connection between informal institutions and behaviour postulated in the conceptual framework section of this article implies that the incidence of violations of traffic laws in South Africa is 


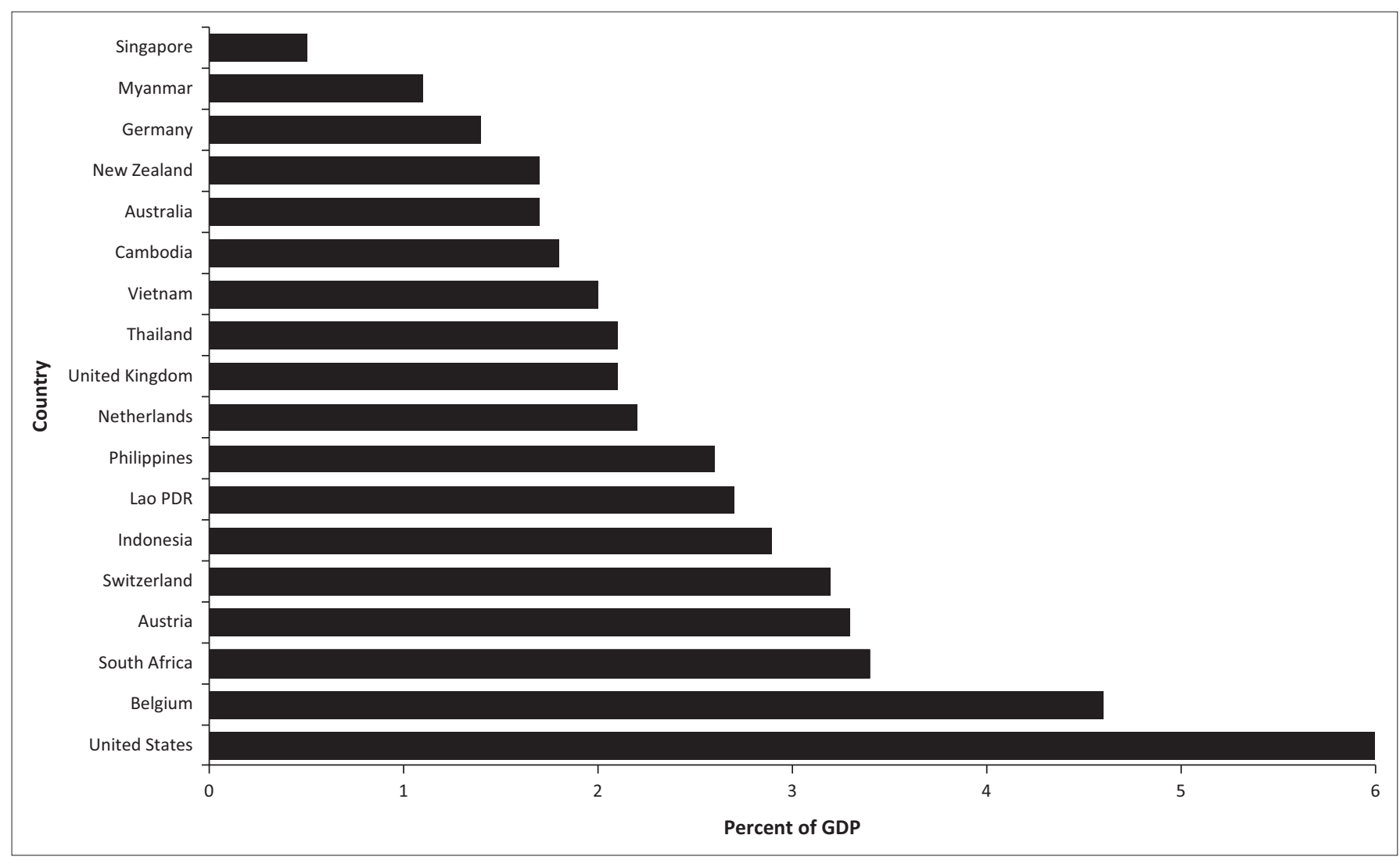

Sources: Road Traffic Management Corporation (RTMC), 2016b, Costs of crashes in South Africa, p. 36, Road Traffic Management Corporation, Pretoria; and Wijnen, W. \& Stipdonk, H., 2016, 'Social costs of road crashes: An international analysis', p. 105, Accident Analysis and Prevention 94, 97-106. https://doi.org/10.1016/j.aap.2016.05.005

GDP, gross domestic product.

FIGURE 3: Latest estimates of the costs of road crashes in 18 countries (percentages of gross domestic product).

one such proxy. Table 2 shows that a recent survey reported 6333177 infringements of traffic laws in South Africa from February 2015 to September 2016 (RTMC 2016c:9-10). This number implies 0.6 infringements of traffic laws per self-propelled vehicle listed in the National Traffic Information System (eNATIS) of the RTMC. ${ }^{5}$ Although indicative of a high incidence of violation of traffic laws, this ratio significantly understates the extent of the problem. Many infringements go undetected, and data for only 17 of the 20 months were useable for inclusion in the survey report. Moreover, the survey contains information compiled by the National Traffic Police and the nine provincial traffic departments. It excludes data on offences in five major cities (Cape Town, Ethekwini, Ekuruleni, Johannesburg and Tshwane), where metropolitan police forces are responsible for enforcing traffic laws. This is a large omission: the City of Cape Town, for example, reported 3873818 infringements of traffic laws in the two-year period from July 2014 to July 2016 (cf. the section on the effectiveness of enforcement of fines for offences).

The vast majority of the infringements listed in Table 2 would have raised the likelihood or human cost of road accidents. These included overloading of vehicles ( $49.8 \%$ of all offences), using vehicles with various defects $(15.3 \%)$, failure to wear seat on 31 January 2015. By October 2019, this number had increased to 11472664 . See Road Traffic Management Corporation (2019). belts $(6.8 \%)$ and speeding (4.3\%). It is notable, however, that only $11.7 \%$ of all offences were linked to key behavioural risk factors identified by the WHO (speeding, driving under the influence, failure to wear seat belts and using mobile phones while driving). Furthermore, a large portion of the listed offences were not direct causes of road accidents. These included infringements of vehicle licensing laws, which totalled $7.9 \%$ of all offences in this period. In addition, 209457 of the 423114 offences of driving documents laws represented instances of drivers who held valid professional drivers' permits or drivers' licences but were unable to present these when asked to do so by traffic officers. This raises the question whether law enforcement efforts in South Africa are focused on the most important causes of road accidents. The focus areas of law enforcement actions section of this article returns to this issue.

Other proxies also suggest that South Africa's poor road safety outcomes partly reflect risky behaviour probably influenced by informal institutions. International comparisons highlight three examples (cf. World Health Organisation 2018:302-313, 334-345, 358-369). The first is that $38.4 \%$ of the victims of fatal road accidents in South Africa in 2016 were pedestrians. The reality that this ratio was lower in 106 of the 129 countries for which the WHO provided data suggests a relatively high prevalence of risky behaviour among pedestrians in South Africa. The second indicator of risky behaviour is the high incidence of alcohol use among road users (including pedestrians). Fully $57.5 \%$ of all road deaths 
TABLE 2: Reported traffic offences in South Africa (February 2015 to September 2016)

\begin{tabular}{|c|c|c|}
\hline \multirow[t]{2}{*}{ Offence types } & \multicolumn{2}{|c|}{ Reported offences } \\
\hline & Number & $\%$ \\
\hline Driving documents & 514820 & 8.1 \\
\hline Driving licence (none or fail to carry) & 164364 & 2.6 \\
\hline Professional driving permit (none or fail to carry) & 258750 & 4.1 \\
\hline Other & 91706 & 1.4 \\
\hline Moving offences & 4775320 & 75.4 \\
\hline Inconsiderate driving and dangerous overtaking & 104782 & 1.7 \\
\hline Violations of road signs and traffic signals & 54970 & 0.9 \\
\hline Stopping on freeways & 8755 & 0.1 \\
\hline Speeding offences & 268735 & 4.2 \\
\hline Seat belt offences & 432417 & 6.8 \\
\hline Unlicensed vehicles & 329667 & 5.2 \\
\hline Fail to display licence disc or operator card & 170334 & 2.7 \\
\hline Overloading (goods) & 2038724 & 32.2 \\
\hline Overloading (passengers) & 1115462 & 17.6 \\
\hline Mobile phone held in hand while driving & 13371 & 0.2 \\
\hline Other & 238103 & 3.8 \\
\hline Vehicle defects & 849647 & 13.4 \\
\hline Steering & 53814 & 0.8 \\
\hline Windscreen wipers & 9271 & 0.1 \\
\hline Brakes & 97631 & 1.5 \\
\hline Tyres & 98000 & 1.5 \\
\hline Front and rear lamps and direction indicators & 371470 & 5.9 \\
\hline Side and rear reflective markings & 187839 & 3.0 \\
\hline Other & 31622 & 0.5 \\
\hline Roadworthiness & 119367 & 1.9 \\
\hline Vehicles discontinued and impounded & 119367 & 1.9 \\
\hline Arrests & 74023 & 1.1 \\
\hline Drunken driving & 27143 & 0.4 \\
\hline Speeding & 1667 & 0.0 \\
\hline Overloading (goods) & 2688 & 0.0 \\
\hline Pedestrians arrested & 25097 & 0.4 \\
\hline Other & 17428 & 0.3 \\
\hline Grand total & 6333177 & 100.0 \\
\hline
\end{tabular}

December 2016, pp. 9-10, Road Traffic Management Corporation, Pretoria.

in South Africa in 2016 were attributable to alcohol - a ratio exceeded by only 4 of the 94 countries for which the WHO provided data. The third is low seat belt usage. In 2016, only 8 of the 76 countries for which the WHO provided data had lower seat belt usage ratios among drivers than South Africa's 33.0\%.

\section{Enforcement of road safety laws in South Africa}

The evidence presented in the previous section, adherence to road safety laws in South Africa, suggests that informal institutions (i.e. the values and norms of many road users) contribute to South Africa's poor road safety outcomes by undermining the effectiveness of the formal institutions (i.e. traffic laws). As was argued in the conceptual framework section of this article, one of the responses available to policymakers when faced with such situations is stricter law enforcement. This section discusses the enforcement of traffic laws and regulations in South Africa. The institutional background section sets the scene by outlining the institutional framework governing traffic law enforcement in South Africa. Against this backdrop, the focus areas of law enforcement actions section comments on the extent of alignment between law enforcement actions and the main causes of deaths and accidents on South Africa's roads, while the section on effectiveness of enforcement of fines for offences confirms the poor functioning of the current adjudication and sanctioning mechanisms. The focus areas of law enforcement actions and effectiveness of enforcement of fines for offences sections use information on traffic law enforcement in the City of Cape Town to support these arguments. The reason for the focus on Cape Town is that officials made an unpublished administrative data set of traffic law violations in the City from July 2014 to July 2016 available to the authors. While this reliance on the situation in one city obviously limits the external validity of the argument, there is no compelling reason to assume that the effectiveness of traffic law enforcement is markedly different elsewhere in South Africa. In addition, the remainder of this section complements the analysis of the Cape Town data set with other published information on road safety outcomes in South Africa.

\section{Institutional background}

The Constitution of South Africa (Act No. 108 of 1996, as amended) apportions responsibility for the making and implementation of road traffic-related legislation among the national, provincial and local governments. Schedule 4 of the Constitution lists public transport, road traffic regulation, vehicle licensing and municipal public transport among the functional areas of concurrent national and provincial legislative competence. Schedule 5 includes provincial roads and traffic, municipal roads and traffic and parking among the functional areas of exclusive provincial legislative competence. Some of these matters (municipal public transport, municipal roads and traffic and parking) appear in Part B of Schedule 4 and Part B of Schedule 5. Section 156 of the Constitution assigns executive authority and administrative rights in respect of such matters to municipalities.

This division of responsibilities across levels of government has complicated road traffic management in South Africa. Hence, the RTMC was established in 1999 'to pool powers and resources and to eliminate the fragmentation of responsibilities for road traffic management across the various spheres of government' (RTMC 2016a:16). The RTMC functions at arms length from the Department of Transport. It has a Shareholders Committee consisting of the national Minister of Transport, the Members of the Provincial Executive Councils responsible for transport, and two representatives nominated by organised local government. The functions of the RTMC range from training of traffic personnel, provision of road traffic information and vehicle registration and licensing to road traffic law enforcement and adjudication of road traffic offences.

The current legal framework for the latter function is the Administrative Adjudication of Road Traffic Offences 
(AARTO) Act (No. 46 of 1998). The AARTO Act was supposed to have replaced the previous regime in terms of which the Criminal Procedure Act (No. 51 of 1977) was the framework for the administration of all violations of traffic regulations. That system functioned poorly: transgressors paid fines in fewer than $20 \%$ of cases related to traffic regulations (AARTO Background, undated). Apart from inappropriate informal institutions (notably a strong culture of non-payment of fines), this state of affairs reflected various shortcomings in formal institutions: some courts resolved to hear only a limited number of cases linked to infringements of traffic laws because of heavy caseloads, aspects of the adjudication process led courts to refuse to consider large numbers of traffic notices, magistrates often reduced traffic fines substantially, and bribing of traffic officials was widespread (AARTO Background, undated).

One of the key objectives of the AARTO Act is to establish better procedures for the adjudication of traffic law infringements that would encourage compliance with these laws and alleviate the burden on courts of law (AARTO Background, undated). To this end, the Act (South Africa 1998) distinguishes between three categories of traffic law violations. While the AARTO Regulations categorise some violations as 'offences' that have to be dealt with by the courts under the Criminal Procedure Act, the majority are categorised as 'minor infringements' or 'major infringements'. The Act establishes an administrative process for the adjudication and enforcement of all such infringements. A streamlined fine system and a demerit points system (which provides for the suspension and cancellation of driving licences or permits of repeat offenders) are core components of this process.

Administrative Adjudication of Road Traffic Offences pilot projects were launched in the cities of Johannesburg in 2007 and Tshwane (Pretoria) in 2008. Elsewhere in South Africa, including Cape Town, the implementation of AARTO has been delayed by legal challenges, inter alia. Hence, the Criminal Procedure Act remains the de facto legal framework for traffic law enforcement fully 20 years after the formal adoption of the AARTO Act.

\section{Focus areas of law enforcement actions}

The South African traffic authorities undertake a large number of law enforcement actions every year. From February 2015 to September 2016, for example, the national and provincial traffic authorities held 56815 roadblocks, stopped 16233847 vehicles, weighed 2950735 vehicles and tested 211432 drivers for alcohol (RTMC 2016c:8). The traffic departments of local authorities are also very active. Nonetheless, there is much concern about the overall effectiveness of traffic law enforcement. This is confirmed by the generally weak to modest law enforcement scores provided to the WHO by South African experts (cf. Table 3)

One of the key aspects of traffic law enforcement is whether the actions of the authorities target the leading causes of road accidents. To explore this issue, the remainder of this subsection compares such causes with the numbers of fines issued by the City of Cape Town for violations of various traffic regulations.

Table 4 summarises the leading causes of road crashes in the City of Cape Town in 2014. The data set provided by the City's Traffic Department distinguishes among four types of crashes (those that resulted in deaths, serious injuries, slight injuries and unspecified injuries) and lists more than 50 causes. To compile Table 4, the first two types of crashes were combined and the recorded causes grouped into 13 categories. Some categories may well overlap (for example, 'Pedestrians' and 'Hit and run'), but the format in which the data were captured prevents finer-grained classification. Seven categories of causes were responsible for $90 \%$ of the crashes that resulted in deaths and serious injuries. Pedestrians caused more than a third of such crashes. The second most important category was failure to control a vehicle, which caused $15.6 \%$ of crashes. This category includes four causes in the data set, namely 'Swerving', 'Lost control', 'Drunk in charge' and 'Blackouts and falling asleep'. Hit-and-run incidents (12.0\%) and turning and lane changing errors $(9.5 \%$, consisting of 'Turning in the face of oncoming traffic', 'Changing lane while unsafe', 'Making a U-turn when unsafe', 'Failing to stay in lane', 'No sign of turning', 'Driving on the wrong side', and 'Failing to keep left') were the next most prominent category of causes. These were followed by failure to stop at traffic lights and stop streets $(6.3 \%)$, other driver errors $(5.3 \%$, consisting of 'Did not yield', 'Entered traffic while unsafe', 'Vehicle reversed', 'Driving too fast', 'Ignored barrier lines', 'Cut in front of others' and 'Other'; 6.0\%) and failure to maintain adequate following distances.

The same seven categories also caused almost $85 \%$ of the crashes that resulted in slight injuries. Pedestrians (19.6\%) were the most important causes of such crashes as well, followed by failure to maintain adequate following distances $(18.6 \%)$, turning and lane changing errors (13.7\%) and failure

TABLE 3: Expert-provided law enforcement scores for South Africa (2009-2018).

\begin{tabular}{|c|c|c|c|c|}
\hline \multirow[t]{2}{*}{ Law } & \multicolumn{4}{|c|}{ Enforcement scores: 0 (weakest) - 10 (strongest) } \\
\hline & 2009 & 2013 & 2015 & 2018 \\
\hline National speed limit & 3 & 3 & 3 & 6 \\
\hline National driving under the influence law & 2 & 2 & 4 & 5 \\
\hline National motorcycle helmet law & 6 & 6 & 5 & 8 \\
\hline National seat belt law & 2 & 1 & 2 & 5 \\
\hline
\end{tabular}

Source: World Health Organisation (2009:192, 2013:204, 2015:226, 2018:235).

Note: Please see the full reference list of the article, Du Plessis, S., Jansen, A. \& Siebrits, K., 2020, 'The limits of laws: Traffic law enforcement in South Africa', South African Journal of Economic and Management Sciences 23(1), a3430. https://doi.org/10.4102/sajems.v23i1.3430, for more information. 
TABLE 4: Leading causes of road crashes in the City of Cape Town (2014).

\begin{tabular}{|c|c|c|c|c|c|c|}
\hline \multirow[t]{2}{*}{ Causes of accidents } & \multicolumn{2}{|c|}{ Serious injuries } & \multicolumn{2}{|c|}{ Slight injuries } & \multicolumn{2}{|c|}{ Unspecified injuries } \\
\hline & Number & $\%$ & Number & $\%$ & Number & $\%$ \\
\hline Pedestrians & 1054 & 35.3 & 2326 & 19.6 & 79 & 4.2 \\
\hline Failure to control vehicle & 465 & 15.6 & 1567 & 13.2 & 188 & 9.9 \\
\hline Hit and run & 357 & 12.0 & 215 & 1.8 & 33 & 1.7 \\
\hline Turning and lane changing & 283 & 9.5 & 1627 & 13.7 & 327 & 17.2 \\
\hline Failure to stop & 187 & 6.3 & 959 & 8.1 & 95 & 5.0 \\
\hline Insufficient following distance & 159 & 5.3 & 2208 & 18.6 & 449 & 23.7 \\
\hline Animals and objects & 96 & 3.2 & 611 & 5.1 & 70 & 3.7 \\
\hline Overtaking & 86 & 2.9 & 385 & 3.2 & 154 & 8.1 \\
\hline Vehicle defects & 60 & 2.0 & 325 & 2.7 & 19 & 1.0 \\
\hline Parking and stopping & 34 & 1.1 & 382 & 3.2 & 134 & 7.1 \\
\hline Weather and road conditions & 9 & 0.3 & 86 & 0.8 & 3 & 0.2 \\
\hline Miscellaneous & 13 & 0.4 & 39 & 0.3 & 4 & 0.2 \\
\hline
\end{tabular}

Source: City of Cape Town Traffic Department, 2016, Unpublished data on offences from July 2014 to July 2016, City of Cape Town Traffic Department, Cape Town.

TABLE 5: The 20 traffic offences for which most fines were issued in the City of Cape Town (July 2014-July 2016).

\begin{tabular}{|c|c|c|c|}
\hline \multirow[t]{2}{*}{ Code } & \multirow[t]{2}{*}{ Description } & \multicolumn{2}{|c|}{ Frequency of offence } \\
\hline & & Number & $\%$ \\
\hline 11522 & Exceeding general speed limit of $60 \mathrm{~km} / \mathrm{h}$ in an urban area: $71-74 \mathrm{~km} / \mathrm{h}$ & 536790 & 13.9 \\
\hline 78320 & Operating a motor vehicle without a licence disc or licence and roadworthy certificate affixed on inside of windscreen as prescribed & 471613 & 12.2 \\
\hline 78011 & Driver using unlicensed vehicles & 465629 & 12.0 \\
\hline 11530 & Exceeding general speed limit of $60 \mathrm{~km} / \mathrm{h}$ in an urban area: $75-79 \mathrm{~km} / \mathrm{h}$ & 389680 & 10.1 \\
\hline 14708 & Exceeded the speed limit of $80 \mathrm{~km} / \mathrm{h}$ & 203316 & 5.3 \\
\hline 11548 & Exceeding general speed limit of $60 \mathrm{~km} / \mathrm{h}$ in an urban area: $80-84 \mathrm{~km} / \mathrm{h}$ & 183952 & 4.8 \\
\hline 14716 & Exceeding speed limit of $80 \mathrm{~km} / \mathrm{h}$ indicated by a road sign: $91-94 \mathrm{~km} / \mathrm{h}$ & 151894 & 3.9 \\
\hline 11556 & Exceeding general speed limit of $60 \mathrm{~km} / \mathrm{h}$ in an urban area: $85-90 \mathrm{~km} / \mathrm{h}$ & 97085 & 2.5 \\
\hline 14724 & Exceeding speed limit of $80 \mathrm{~km} / \mathrm{h}$ indicated by a road sign: $95-99 \mathrm{~km} / \mathrm{h}$ & 85721 & 2.2 \\
\hline 20458 & Disregarding a no-stopping red line & 72818 & 1.9 \\
\hline 11564 & Exceeding general speed limit of $60 \mathrm{~km} / \mathrm{h}$ in an urban area: $90 \mathrm{~km} / \mathrm{h}+$ & 72646 & 1.9 \\
\hline 20482 & Disregarding a no-parking yellow line & 72061 & 1.9 \\
\hline 13451 & Speed: 50 LMV (60-64) & 70547 & 1.8 \\
\hline 20149 & Parking in a loading zone & 65278 & 1.7 \\
\hline 83812 & Parking on the sidewalk & 48645 & 1.3 \\
\hline 14732 & Exceeding speed limit of $80 \mathrm{~km} / \mathrm{h}$ indicated by a road sign: $100-104 \mathrm{~km} / \mathrm{h}$ & 48219 & 1.3 \\
\hline 14300 & Speed: 70 LMV (81-84) & 45606 & 1.2 \\
\hline 13469 & Speed: 50 LMV (65-69) & 42010 & 1.1 \\
\hline 14318 & Exceeding speed limit of $80 \mathrm{~km} / \mathrm{h}$ indicated by a road sign: $81-84 \mathrm{~km} / \mathrm{h}$ & 40498 & 1.1 \\
\hline- & Other (including 2101 without descriptions) & 640338 & 16.5 \\
\hline- & Total & 3873812 & 100.0 \\
\hline
\end{tabular}

Source: City of Cape Town Traffic Department, 2016, Unpublished data on offences from July 2014 to July 2016, City of Cape Town Traffic Department, Cape Town.

to control a vehicle (13.2\%). It is clear that the vast majority of road crashes in the City of Cape Town would not have occurred if the formal and informal institutions had significantly reduced these seven sets of causes.

A superficial analysis of the fines issued for violations of traffic regulations might suggest that the law enforcement efforts in Cape Town were too narrow in scope to have prevented the large number of road crashes. South Africa's traffic regulations distinguish among many offences: the data set provided by the City's Traffic Department contains 746 distinct types. Yet the vast majority of fines are issued for a small subset of these offences. Table 5 shows that $68.7 \%$ of all fines were issued for the 10 most common offences. Seven of these were related to violations of speed limits, two to infringements of vehicle licensing regulations and the tenth for disregarding of no-stopping lines. The next 10 most common offences consisted of a further six violations of speed limits, three infringements of parking regulations, and disregarding of traffic lights. These 20 offences accounted for fully $83.5 \%$ of all the fines issued. Slightly more than $60 \%$ of the fines issued for these offences were for speeding, nearly $30 \%$ for licensing-related offences and slightly fewer than $10 \%$ for stopping and parking offences.

Prevention of these offences should contribute to improved road safety outcomes. Table 4 shows that failure to stop at traffic lights and stop streets resulted in $6.3 \%$ of the crashes that caused deaths and serious injuries in 2014 and $8.1 \%$ of the crashes that caused slight injuries. Furthermore, one of the purposes of the vehicle licensing regulations is to lower the incidence of defect-related crashes by reducing the 


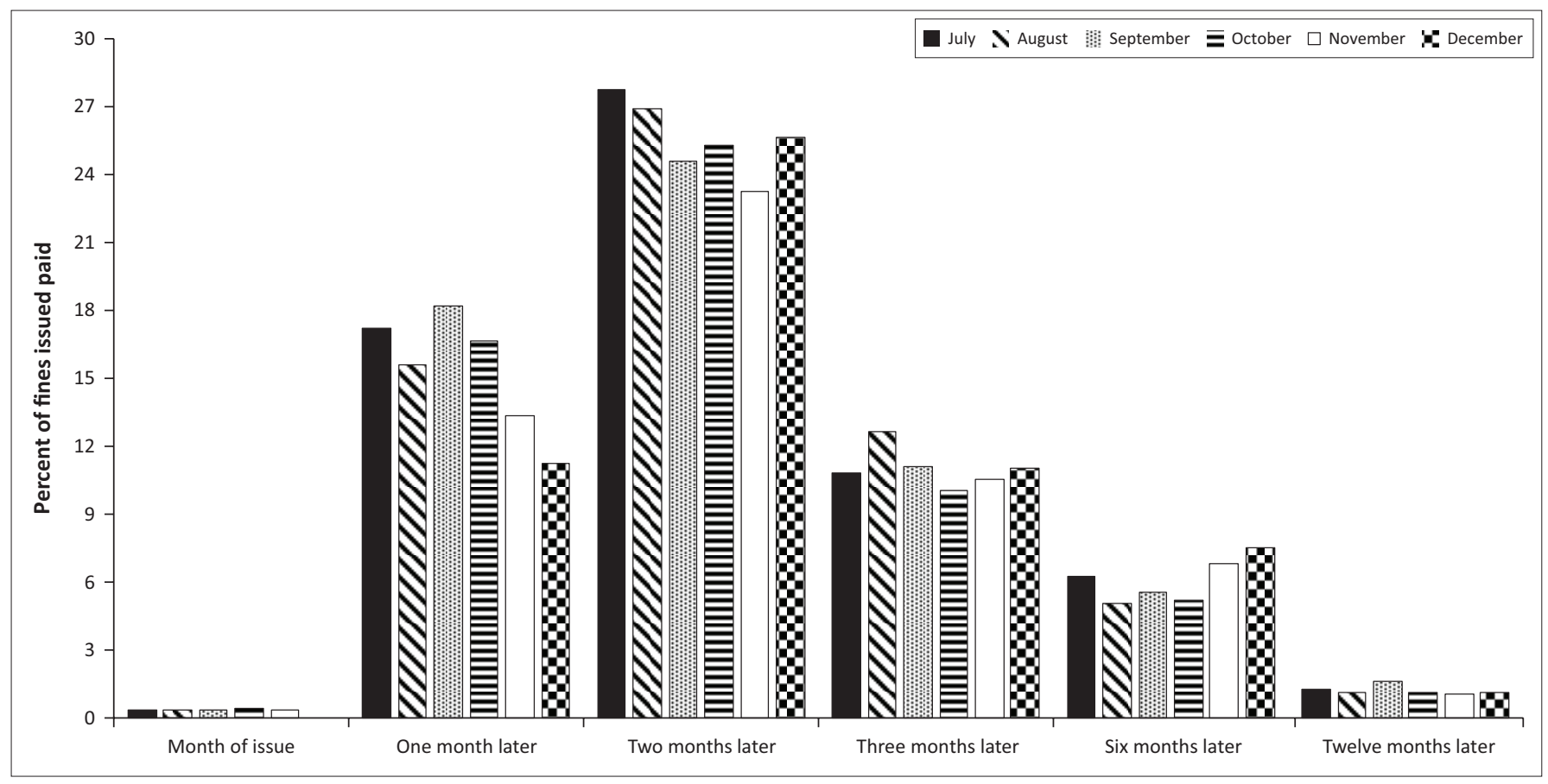

Source: Own calculations based on unpublished data provided by the City of Cape Town Traffic Department, 2016, Unpublished data on offences from July 2014 to July 2016 , City of Cape Town Traffic Department, Cape Town.

FIGURE 4: Evolution of payments for speeding-related fines issued from July 2014 to December 2014 (percentages of issued fines).

numbers of non-roadworthy vehicles. And although it is not included among the causes of road crashes summarised in Table 4, speeding is likely to be an important reason for failure to control vehicles and a major determinant of the damages associated with other causes of road crashes (such as collisions with people, animals and objects, hit-and-run incidents, and failures to maintain adequate following distances). ${ }^{6}$ Hence, it is essential to impose fines on violators of these three sets of traffic regulations. Yet the statistics on fines suggest that other forms of behaviour that also caused many serious crashes are much less likely to be punished. The most notable of these are jaywalking and dangerous turning, overtaking and changing of traffic lanes.

It would be incorrect, however, to interpret the statistics on fines issued as indicative of a lopsided law enforcement effort that focuses excessively on speeding and neglects other major causes of road crashes. The road safety strategy of the City of Cape Town (2013) for the period 2013 to 2018 shows a strong awareness of the full range of causes of road crashes and contains objectives and action plans for handling each of them. The apparent disjunction between the statistics in Table 4 and Table 5 largely reflect the reality that some offences are markedly easier than others to detect and fine. The authorities rely heavily on fixed and portable cameras to identify instances of speeding and ignoring of traffic lights and use roadblocks and patrolling officers to identify infringements of licensing and parking regulations. Offences such as jaywalking and dangerous overtaking occur at random times in random places, and detection depends on whether traffic officers happen to be in the vicinity. Law enforcement, no matter how

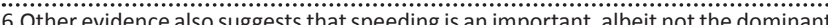
cause of serious road accidents in South Africa. The Road Traffic Management Corporation (2016c:24-26) reports that inappropriately high speeds caused $9.2 \%$ of Corporation (2016c:24-26) reports that inappropriately high speeds caused $9.2 \%$ of all fatal accidents in South Africa in 2014 and 2015 . Jaywalking pedestrians
responsible for $41.6 \%$ of such accidents, and hit-and-run incidents for $8.8 \%$. effective, might not suffice to eradicate such causes of road crashes. Hence, Section 6 argues that appropriate values and norms (that is, informal institutions) must complement law enforcement to achieve this goal.

\section{The effectiveness of enforcement of fines for offences}

The data set provided by the Traffic Department of the City of Cape Town contains various details of each violation of a traffic regulation from July 2014 to July 2016, including a descriptions of the offence, the date of the notice of the offence, the fine issued, whether the charge was withdrawn, and the amount paid (if applicable). This subsection uses some of these details to show that non-detection of behaviour that causes crashes is by no means the only weakness in the enforcement of traffic regulations in South Africa. The following analysis confirms another shortcoming already identified and partly explained in the institutional background section of this article: only a small proportion of offenders actually pay the fines imposed for violations of traffic regulations.

It transpires from the data set that only $26 \%$ of all traffic fines issued in the City of Cape Town from July 2014 to July 2016 had been paid by the end of August 2016. To be sure, payment patterns over the period as a whole suggested that some of the outstanding fines would have been settled after the end of August. However, such delayed payments would not have had a dramatic effect on the overall payment rate. The basis for this claim is the typical pattern of payments, which is illustrated by the evolution of payment rates for speeding-related fines issued in the second half of 2014 (cf. Figure 4). Hardly any

7.The information in Figure 4 relates to the 13 speeding-related offences included among the 20 most common fined offences listed in Table 4. 


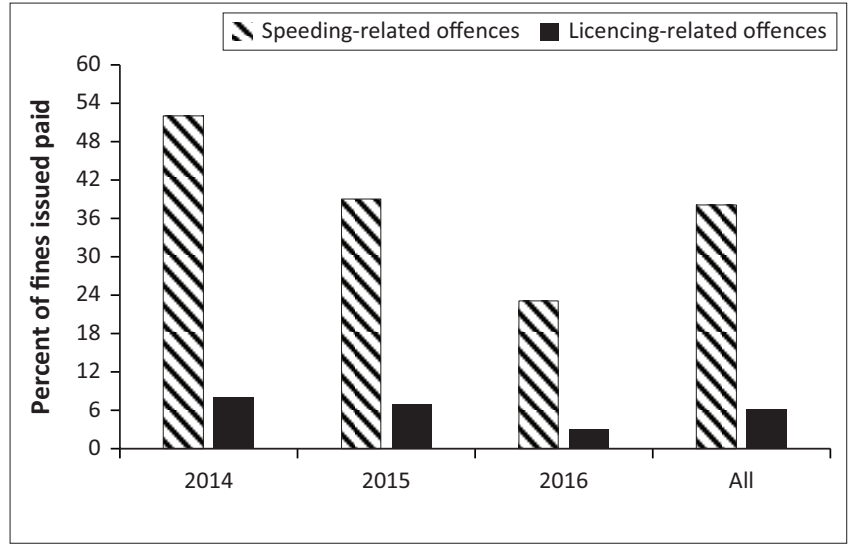

Source: Authors' own calculations based on unpublished data provided by the City of Cape Town Traffic Department, 2016, Unpublished data on offences from July 2014 to July 2016 City of Cape Town Traffic Department, Cape Town.

FIGURE 5: Payment rates for speeding-related and licensing-related traffic fines issued from July 2014 to July 2016 (percentages as at the end of August 2016).

fines were paid in the months of issue, largely because it took time to notify offenders via the postal system. The bulk of compliant offenders paid during the two months after the ones in which fines were issued, and payments decreased notably and steadily in subsequent months. Fewer than $2 \%$ of fines were paid more than a year after the date of issue.

Figure 5 shows that the payment rates for speeding-related fines were significantly higher than those for licensingrelated ones in all three years. ${ }^{8}$ There is no obvious reason for this large differential. Figure 5 illustrates another important yet unexplained pattern, namely that payment rates for offences committed in 2016 were markedly lower than those for offences committed in 2014 (the decrease for speedingrelated offences was from $52 \%$ to $23 \%$ and that for licensingrelated offences from $8 \%$ to $3 \%$ ). As was shown earlier, payments after the end of August 2016 probably would not have changed this pattern much. Hence, it may well reflect the growing realisation among offenders that non-payment has no consequences.

It hardly needs to be pointed out that such high rates of non-payment severely diminish the deterrence effect of the fine system. This is an administrative issue that, in principle, should be much easier to resolve than the detection problem discussed in the focus areas of law enforcement actions section of this article. The requirement is a well-designed administrative process that simplifies and expedites enforcement of sanctions for infringements of traffic laws. As was pointed out in the institutional background section of this article, this was the aim of the long-delayed AARTO system.

\section{Conclusion and policy implications}

This article uses the road safety situation in South Africa as a context for exploring ideas from the New Institutional Economics about the links between informal institutions and the nature and enforcement of formal institutions.
By international standards, South Africa has a strong suite of road safety laws but poor road safety outcomes. The point of departure of the article is the claim that this state of affairs confirms a core insight of the New Institutional Economics, namely the pivotal influence on the effectiveness of formal institutions of good enforcement and supportive informal institutions. In support of this claim, the article argues that inappropriate values and norms seemingly underpin the behaviour of many South Africans road users and that two major weaknesses mar the enforcement of traffic laws. These are that some of the most important causes of serious road crashes in South Africa by nature are extremely difficult to detect and punish and that the administrative and legal processes for punishing transgressors of traffic laws function very poorly. The second problem seems solvable; in fact, a legal framework for this purpose (the AARTO Act) has been in existence for almost two decades. With the necessary political will, it should be possible to deter many transgressions of traffic laws by more effective penalisation of reckless and negligent behaviour. The first issue is more problematic: in the foreseeable future, technological and resource constraints will continue to hamper efforts by the traffic authorities to credibly threaten all potential offenders with detection and punishment. The policy implication of this analysis is that improvement of road safety outcomes in South Africa requires law enforcement reforms, as well as changes to the informal institutions shaping the behaviour of road users.

It is clear from policy documents and statements that policymakers are aware of the need for such a two-pronged approach to improving the road safety situation. The following passage in an annual report of the Road Traffic Infringement Agency (2015) confirms this:

World-wide best practices have proven that for law enforcement to be effective, it must be supported by an equally effective public awareness, communication and education programme, as well as a highly efficient, transparent and expeditious adjudication process to bring traffic offenders to task. (p. 26)

Outcomes, however, suggest that attempts to augment law enforcement activities with programmes aimed at changing road user behaviour (such as the 'Arrive Alive' campaign - cf. Arrive Alive 2017) have borne little fruit in South Africa. Many similar attempts in other areas of policymaking marked by conflict between formal and informal institutions have also yielded disappointing results. This raises the question whether institutional economists understand the requirements for changing values and norms well enough to provide advice that would strengthen such attempts. Some economists (e.g. Young 1996) have studied the origins of informal institutions, and many theories of institutional change incorporate informal institutions (cf. Kingston \& Caballero 2009). Yet much of the existing theoretical work on informal institutions by economists has relied on questionable assumptions about the rationality properties of human behaviour.

Cognitive and behavioural scientists, however, have made considerable progress as far as understanding change in values and norms is concerned (see, for example, the overview 
by Bicchieri \& Mercier 2014). Thus far, only a small number of economists (including Aldashev et al. 2010; Denzau \& North 1994) have included insights from behavioural and cognitive science into writings on informal institutions. Hence, Field's (2007) appeal to institutional economists to take a greater interest in the insights generated by research in these and other disciplines such as biology and neuroscience remains valid. Taking heed of this appeal should be a priority for institutional economists working in this field.

Another rich source of ideas that institutional economists should draw upon more actively is the burgeoning field of behavioural economics. One of the ideas that has emerged from behavioural economics is the notion of a nudge, that is, 'an aspect of the choice architecture that alters people's behavior in a predictable way without forbidding any options or significantly changing their economic incentives' (Thaler \& Sunstein 2008:6). Preliminary evidence has suggested that nudges, which should be cheap and easy to avoid, can be useful complements to formal institutions intended to change behaviour. ${ }^{9}$ Various other insights from research in behavioural economics should also enhance institutional economists' understanding of the forces that shape and change values and norms and, hence, their ability to provide useful advice in settings where such change is an important policy objective.

\section{Acknowledgements}

This article is one of the outputs of a project on traffic law enforcement in South Africa funded by the National Research Foundation (NRF) (grant no: 118562). The authors gratefully acknowledge this funding. All errors in this article should be attributed to the authors, and opinions expressed in the article do not necessarily reflect those of the NRF.

\section{Competing interests}

The authors have declared that no competing interest exists.

\section{Authors' contributions}

All authors contributed equally to this work.

\section{Funding information}

This article is one of the outputs of a project on traffic law enforcement in South Africa funded by the National Research Foundation (NRF) (Grant number: 118562).

\section{Ethical consideration}

Stellenbosch University, Research Ethics Committee: Human Research (Humanities), SU-HSD-001857, Ethical Clearance Number: SU-HSD-001857, 21 April 2016.

\footnotetext{
9.The use of 'speed reduction markings' on a curve in Lake Shore Drive in Chicago is a well-known example of a road safety-related nudge (cf. Thaler \& Sunstein 2008:37-39). These markings are a series of white stripes painted on the road. Initially, the stripes These markings are a series of white stripes painted on the road. Initially, the stripes
are evenly spaced, but they get closer together at the most dangerous part of the curve. This creates the sensation of increasing speed, which makes many drivers slow curve. This creates the sensation of increasing speed, which makes many drivers slow
down. The previously unacceptable number of accidents on that section of the road down. The previously unacceptable number of accidents on that section of the roy
decreased sharply in the six-month period after the markings were introduced.
}

\section{Data availability statement}

Data sharing is not applicable to this article as no new data were created or analysed in this study.

\section{Disclaimer}

The views and opinions expressed in this article are those of the authors and do not necessarily reflect the official policy or position of any affiliated agency of the authors.

\section{References}

Administrative Adjudication of Road Traffic Offences, Undated, AARTO background viewed 17 December 2019, from http://www.enatis.com/index.php/ statistics/13-live-vehicle-population.

Aldashev, G., Imane, C., Platteau, J.-P. \& Wahhaj, Z., 2010, 'Using the law to change the custom', Journal of Development Economics 97(2), 182-200. https://doi. org/10.1016/j.jdeveco.2011.03.001

Arrive Alive, 2017, Official website of the arrive alive campaign, viewed 05 December 2017, from http://www.arrivealive.co.za.

Bicchieri, C. \& Mercier, H., 2014, 'Norms and beliefs: How change occurs', Jerusalem Philosophical Quarterly 63(1), 60-82. https://doi.org/10.1007/978-3-319-05308-0_3

Bowles, S. \& Polanía-Reyes, S., 2012, 'Economic incentives and social preferences: Substitutes or complements?', Journal of Economic Literature 50(2), 368-425. https://doi.org/10.1257/jel.50.2.368

City of Cape Town Traffic Department, 2013, Road safety strategy for the period 2013-2018, City of Cape Town Traffic Department, Cape Town.

City of Cape Town Traffic Department, 2016, Unpublished data on offences from July 2014 to July 2016, City of Cape Town Traffic Department, Cape Town.

Denzau, A.T. \& North, D.C., 1994, 'Shared mental models: Ideologies and institutions', Kyklos 47(1), 3-31. https://doi.org/10.1111/j.1467-6435.1994.tb02246.x

Festré, A., 2010, 'Incentives and social norms: A motivation-based economic analysis of social norms', Journal of Economic Surveys 24(3), 511-538. https://doi. org/10.1111/j.1467-6419.2009.00594.x

Field, A.J., 2007, 'Beyond foraging: Behavioral science and the future of institutional economics', Journal of Institutional Economics 3(3), 265-291. https://doi. org/10.1017/S1744137407000720

Gneezy, U., Meier, S. \& Rey-Biel, P., 2011, 'When and why incentives (don't) work to modify behavior', Journal of Economic Perspectives 25(4), 1-21. https://doi. org/10.1257/jep.25.4.191

Groenewegen, J., Spithoven, A. \& Van den Berg, A., 2010, Institutional economics: An introduction, Palgrave MacMillan, London.

Kingston, C. \& Caballero, G., 2009, 'Comparing theories of institutional change' Journal of Institutional Economics 5(2), 151-180. https://doi.org/10.1017/ S1744137409001283

National Planning Commission, 2015, National development plan 2030 The Presidency, Pretoria.

North, D.C., 1994, 'Economic performance through time', American Economic Review 84(3), 359-368.

North, D.C., 2005 'Institutions and the performance of economies over time', in C. Ménard and M.M. Shirley (eds.), The handbook of new institutional economics, pp. 21-30, Springer, Amsterdam.

Pejovich, S., 1999, 'Effects of the interaction of formal and informal institutions on social stability and economic development', Journal of Markets and Morality 2(2), 164-181.

Polinsky, A.M. \& Shavell, S., 2007, 'The theory of public enforcement of law', in A.M. Polinsky \& S. Shavell (eds.), The handbook of law and economics, pp. 403-454, Elsevier, Amsterdam.

Road Traffic Infringement Agency, 2015, Annual report 2014/15, Road Traffic Infringement Agency, Pretoria.

Road Traffic Management Corporation (RTMC), 2016a, Annual report 2015/16, Road Traffic Management Corporation, Pretoria.

Road Traffic Management Corporation (RTMC), 2016b, Costs of crashes in South Africa, Road Traffic Management Corporation, Pretoria.

Road Traffic Management Corporation (RTMC), 2016c, Traffic offence survey December 2016, Road Traffic Management Corporation, Pretoria.

Road Traffic Management Corporation (RTMC), 2019, Live vehicle population as per the National Traffic Information System - eNaTIS, viewed 17 December 2019, from http://www.enatis.com/index.php/statistics/13-live-vehicle-population.

South Africa, 1998, Administrative adjudication of road traffic offences act (No 46 of 1998), Government Printer, Pretoria.

Statistics South Africa, 2017, Mortality and causes of death in South Africa, 2015 Findings from death notification, Statistical Release P0309.3, Statistics South Africa, Pretoria.

Thaler, R.H. \& Sunstein, C.R., 2008, Nudge: Improving decisions about health, wealth and happiness, Yale University Press, New Haven, CT. 
Voigt, S. \& Kiwit, D., 1998, 'The role and evolution of beliefs, habits, moral norms, and institutions', in H. Giersch (ed.), The merits and limits of markets, pp. 83-108, Springer, Berlin.

Wijnen, W. \& Stipdonk, H., 2016, 'Social costs of road crashes: An international analysis', Accident Analysis and Prevention 94, 97-106. https://doi.org/10.1016/j. aap.2016.05.005

World Health Organisation, 2009, Global status report on road safety 2009, World Health Organisation, Geneva.
World Health Organisation, 2013, Global status report on road safety 2013, World Health Organisation, Geneva.

World Health Organisation, 2015, Global status report on road safety 2015, World Health Organisation, Geneva.

World Health Organisation, 2018, Global status report on road safety 2018, World Health Organisation, Geneva.

Young, H.P., 1996, 'The economics of convention', Journal of Economic Perspectives 10(2), 105-122. https://doi.org/10.1257/jep.10.2.105 